\title{
Od opowiadania do telegrafu: literatura (nie tylko) o zarazie i problem mediów
}

Jan P. Hudzik

TEKSTY DRUGIE 2021, NR 3, S. 166-182

DOI: 10.18318/td.2021.3.12 | ORCID: 0000-0002-4806-7840

\section{Wprowadzenie}

Izolacja w stanie zarazy, w której uczucie lęku przed bliźnimi miesza się z nieodpartym pragnieniem ich bliskości, naprowadza mnie w czasie pandemii koronawirusa w 2020 roku na trop opowiadania jako medium komunikacyjnego. Zachęca do ryzykownej próby zaproponowania - na tle wybranych utworów z literatury powszechnej o zarazie - pewnej filozoficznej teorii mediów. Media to zjawiska społeczne - ich znaczenie i sposoby użycia zakodowane są kulturowo, wyłaniają się ze społecznych imaginariów opartych na mitach, legendach, wiedzy i religii. Nie zajmuję się jednak hermeneutyką - nie interesują mnie interpretacje utworów literackich. Skupiam się na samym opowiadaniu jako modelu narzucającym na odnośne utwory i opowiadany w nich świat pewne konwencje interpretacyjne. Odróżniam metafizykę od ontologii opowiadania, opartej na (nowoczesnych) podmiotach posługujących się mądrością praktyczną. $\mathrm{Na}$ koniec analizuję literackie reprezentacje telegrafu, pojawiającego się również w kontekście zarazy, choć nie tylko w nim. Co wnoszą one do zrozumienia mediów?
Jan P. Hudzik -

filozof, profesor na Wydziale Politologii

i Dziennikarstwa UMCS, kierownik Katedry Teorii Mediów. Zajmuje się filozofią kultury - ostatnio w szczególności polityki i mediów - historią idei oraz teoretycznymi podstawami nauk społecznych i humanistycznych. Publikacje książkowe najnowsze: Prawda iteoria (2011), Wykłady z filozofii mediów (2017), (wraz z Marcinem Sanakiewiczem i Piotrem Celińskim) Projekt: Media. Wyobrazić sobie media istworzyć świat (2020). 


\section{Zaraza, izolacja i problem opowiadania}

W roku Pańskim 1348 na podflorenckiej wsi spotyka się grupa młodych ludzi - dokładnie dziesięć osób: siedem kobiet - „dam”, „białogłów”, oraz trzech mężczyzn - „kawalerów”. Przez dziesięć dni z dala od szalejącej w mieście „zarazy morowej” będzie ich łączyło wspólne opowiadanie. To dziwne, gdy wokół dżuma, czarna śmierć sieje spustoszenie - w okrutnych mękach masowo giną ludzie i zwierzęta - młodzież w zacisznym odosobnieniu spędza czas - ostatnie chwile swego życia, ta natrętna myśl musiała ich prześladować - na opowiadaniu sobie zmyślonych historyjek. Czy taki scenariusz wydarzeń jest w ogóle prawdopodobny? Historycy literatury podkreślają realizm opowieści Giovanniego Boccaccia, ale dotyczy on raczej charakterów postaci, ich przeżyć, sposobów przedstawiania wydarzeń, a nie samej sytuacji fabularnej. Z tą ostatnią jest problem - gdzieżby było stać na takie fanaberie młodzież, która musiała być przecież wychowana na eschatologicznych wizjach biblijnych, traktujących zarazę jako karę boską za grzechy i zapowiedź nadchodzącego końca świata. „Będzie głód i zaraza, a miejscami trzęsienia ziemi. Lecz to wszystko jest dopiero początkiem boleści" (Mt 24, 7-8) ${ }^{1}$ nieraz musieli zapewne słuchać w kościele tych lub podobnie brzmiących fragmentów Pisma Świętego. W owym czasie religia panowała w centrum życia intelektualnego i duchowego' ${ }^{2}$.

Dziwi zatem, że opowiadanie, a nie modlitwa albo - wręcz przeciwnie, czego bardziej po młodych gorących głowach należałoby się spodziewać, gry i zabawy ku zaspokojeniu cielesnych żądz - pójście na całość, w taką kac-Wa-wę lub kac-Vegas. To zresztą jeden z najstarszych toposów w światowej literaturze podejmującej temat zarazy - najstarszy i chyba najbardziej też wiarygodny wzorzec zachowania. Brutalna prawda o naskórkowości warstwy norm kulturowych, którą na sobie nosimy, przekonani, że oddziela nas ona jakoby od świata zwierząt. Triumf cielesności. Taką informację wysyłał nam już grecki historyk Tukidydes z Aten (ok. 460 - ok. 396 p.n.e.), naoczny świadek zniszczenia moralnego, jakie siała zaraza pośród mieszkańców jego miasta ${ }^{3}$. Prosta kalkulacja: po co wysilać się dla cnót, skoro okrutna śmierć czyha tuż za rogiem, trzeba raczej korzystać z chwili, teraz albo nigdy - ani ludzie, ani bogowie nam w tym nie przeszkodzą. Nihilistyczny eskapizm jako

1 Pismo Święte Starego i Nowego Testamentu, Księgarnia Św. Wojciecha, Poznań 1984.

2 Zob. L. Febvre, H.-J. Martin Narodziny książki, przeł. A. Kocot i M. Wodzińska-Walicka, Wydawnictwa UW, Warszawa 2014, s. 67.

3 Tukidydes Wojna peloponeska, przeł. K. Kumaniecki, Czytelnik, Warszawa 1988, Ks. II, s. 75-76. 
reakcja na epidemię wielekroć powtarza się w literaturze powszechnej.Żeby nie być gołosłownym, przypomnę tylko - przeskakując z górą dwa tysiące lat - że niemal takie same odruchy w reakcji na dżumę, zwaną czerwoną śmiercią, upatrywał książę Prospero, bohater noweli Edgara Allana Poego z 1842 roku. Zaprosił on szlachetnie urodzoną młodzież płci obojga do swojego zamku, gdzie zaryglowawszy drzwi „przed zakusami rozpaczy”, mogli w karnawałowym amoku „drwić z zarazy”, oddawać się „orgii” i „weselnym szałom"4.

Ta opcja to kulturowy evergreen - i może właśnie stąd moje zdziwienie rozwiązaniem fabularnym zaproponowanym przez Boccaccia. Eskapizm protagonistów renesansowych opowiadań nie był jednak reakcją na egzystencjalne problemy nowoczesności - nadmiar bogactwa i pustkę, która zieje nudą. Trudno tu mówić zwłaszcza o nudzie; plaga nudy opanuje dopiero społeczeństwa nowoczesne, szczególnie z tej fazy ich rozwoju, kiedy w nomenklaturze socjologicznej stają się intymne, czyli po tym jak zdołały obalić wszelkie granice tradycyjnie narzucone na podmiot - na autonomiczne $\mathrm{Ja}^{5}$. Florentyńczycy nie mogli być ani znudzeni, ani lekkomyślni, gdy musieli po prostu ratować swoje życie przed zarazą morową, której siła zniszczenia była dokładnie taka sama, jaką znali z przekazów biblijnych. W samotności i trwodze przed niewidzialną siłą, wobec której sztuka medyczna jest bezradna. Jedynie izolacja, dziś lockdownem także zwana, może ją jakoś zmitygować. Tak samo dawniej jak i dziś.

Zaraza w swoich reprezentacjach literackich odsłania zło świata - pustki egzystencjalnej, wszechobecnej „ciemności, ruiny, śmierci” (Poe). Z tego względu budzi potrzebę medium, które przeprowadzi zagrożonych na drugą stronę - istnienia i pełni sensu. Doświadczenia florenckich gawędziarzy pokazują, że tym medium jest samo opowiadanie jako konwencja komunikacyjna; jej znaczeniem oraz kulturowymi warunkami jej możliwości zajmę się w kolejnych dwóch częściach tych rozważań. Rzecz w tym jednak, że figura medium - demona - często pojawia się również w semantycznej strukturze opowiadań. Takim pośrednikiem była np. przerażająca postać w trupiej masce na balu Prospera - pod koniec opowiadania wszyscy biesiadnicy, ukryci przed zarazą za wysokimi murami warowni, ulegają jej czarowi i doznają prawdziwego wyzwolenia, umierając w rozpaczliwych konwulsjach. Podobne doświadczenie spotyka protagonistę jeszcze innego arcymistrzowskiego

4 E.A. Poe Maska śmierci szkarłatnej, przeł. B. Leśmian, różne wydania.

5 R. Sennett Upadek człowieka publicznego, przeł. H. Jankowska, Muza, Warszawa 2009. 
opowiadania, genologicznie rzecz biorąc, podobnie jak w wypadku Maski śmierci szkarłatnej, noweli, a więc gatunku, za którego twórcę uchodzi skądinąd Boccaccio. Tak samo w XIX jak i na początku wieku XX eskapistyczne pragnienia podlegają nadal silnemu tłumieniu kulturowemu, przede wszystkim przez opory moralne. Wypierane impulsy i pragnienia znajdują literackie formy sublimacji. Zanim doszło do znanej nam dziś tyranii intymności w życiu publicznym - anything goes - zaraza mogła jedynie katalizować rezerwuary pożądań i fantazji seksualnych jako tematy dopuszczalne pod szczególnym nadzorem wybranych dyskursów kulturowych. Były to określone gatunki literackie - takie jak powieść gotycka, z elementami tajemnicy, grozy i szaleństwa wykorzystywanymi przez Poego, bądź, jak u Defoe ${ }^{6}$, powieść mieszczańska w formie dziennika, oparta na rzetelnej wiedzy medycznej, prawnej i danych statystycznych - lub formy narracyjne, takie jak strumień świadomości czy opowiadanie marzeń sennych. To ostatnie stało się możliwe do zaakceptowania przez publiczność, która zdążyła się już nieco oswoić z psychoanalizą - Śmierćw Wenecji ukazuje się w 1912 roku.

Czas zarazy, która budzi w ludziach przerażenie, daje niepowtarzalną sposobność, by zrozumieć istotę medium, a wraz z nim i naszą cielesną kondycję. Zrozumieć medium to zatem także móc odpowiedzieć na pytanie, co jesteśmy w stanie przekazać innym ze swego cierpienia - niewymownego i niepowtarzalnego. Ku temu też zmierzają te rozważania.

\section{Metafizyka opowiadania}

Powracam do XIV-wiecznej Florencji. Przypomnę, że wyszedłem od zdziwienia fabularnym zamysłem opowiadania o opowiadaniach. Myślałem tak oto: Po kimś, kto nie postrzega zarazy jako kary boskiej - a o takich postaciach jest tu mowa - i wprost patrzy śmierci w oczy, można by się spodziewać, że ostatnie chwile swego życia spędzi na... rozpuście. Nic z tego. Protagoniści Dekameronu zadowalają się opowiadaniem sobie mniej lub bardziej frywolnych historyjek, czasem zabarwionych erotycznie. Przyjemność werbalna, coś jak seks zmediowany, z drugiej ręki. Ale z punktu widzenia Kościoła i jego etyki to i tak zbyt wiele nieprzyzwoitości, o czym świadczyłoby znalezienie się tego utworu - w połowie wieku XVI - na kościelnym indeksie ksiąg zakazanych. Pospolite opowieści - jak zauważają historycy - przez szlachetną formę książki stawały się alternatywną "skarbnicą

6 D. Defoe Dziennik roku zarazy, przeł. J. Dmochowska, PIW, Warszawa 1959. 
wiedzy"7 wobec tej, która rozwijała się w głównym nurcie ówczesnej kultury zachodniej. Wprowadzały do niego mądrość potoczną i były zapowiedzią powieści, która przychodzi na świat już w epoce druku, tak na dobre dopiero na początku wieku XVII za sprawą Don Kichota.

W świetle aksjologii tegoż nurtu nie tylko opowiadane rzeczy - przedmioty opowieści, takie jak przygody i fantazje erotyczne - lecz także sama wypowiedź narracyjna nie należały do praktyk godnych uznania ani naśladowania. Oparta na scholastyce, kultura ta najwyżej stawiała wartości intelektualne i moralne, zgodne z „normalnymi” dyspozycjami natury ludzkiej. Spróbuję poniżej szkicowo zrekonstruować coś, co można by nazwać metafizyką opowiadania. Wyłoni się ona z rozważań nad znaczeniem ludzkiej komunikacji oraz więzi międzyludzkich, które można odnaleźć u Arystotelesa oraz jego dalekich kontynuatorów - dominikanów. Spośród tych ostatnich wybiorę Mistrza Eckharta (1260-1328), którego spostrzeżenia na potrzeby tych rozważań powinny wystarczyć. Metafizykę opowiadania chciałbym następnie odróżnić od jego ontologii - zwykle używa się obu tych pojęć: metafizyki i ontologii, synonimicznie, ale nie zawsze i nie w tym przypadku.

W dyskursie metafizycznym przyjmuje się - za Arystotelesem - że przez przyjemność dopuszczamy się jedynie niecnych uczynków ${ }^{8}$, co by oznaczało, że przyjaźń nie może mieć z nią nic wspólnego. Przyjaźń ma być dyspozycją trwałą i zachodzić tylko między „ludźmi dobrymi”. Ci ostatni zaś są dla siebie wzajemnie „drugim «ja»” - „rozmowa i wymiana myśli"10 między nimi to w pewnym sensie monolog, jałowa, redundantna komunikacja między "samolubami"11, a każdy z nich czyni dobro „ze względu na siebie samego, bo ze względu na pierwiastek intelektualny, który zdaje się być istotą każdego człowieka"12. Opowiadanie jako opowieść, która rozgrywa się w czasie i opowiada sam przepływ $\mathrm{czasu}^{13}$, nie może być więc formą działania intelektu, oglądającego tylko idee lub istoty rzeczy - to, co bezczasowe lub

7 E. Sarnowska-Temeriusz Zarys dziejów poetyki. Od starożytności do końca XVII w., PWN, Warszawa 1985 , S. 403.

\section{Arystoteles Etyka nikomachejska, przeł. D. Gromska, PWN, Warszawa 1982, s. 48.}

Tamże, s. 349.

Tamże, s. 350.

Tamże, s. 342-343.

Tamże, s. 331.

Zob. P. Ricoeur Czas i opowieść, t. 2: Konfiguracja w opowieści fikcyjnej, przeł. J. Jakubowski, Wydawnictwo U), Kraków 2008, s. 126. 
ponadczasowe. Skoro tak, to opowiadanie - zarówno jako akt snucia opowieści, wypowiedzi narracyjnej, jak i (w kulturze pisanej) akt pisania historii, tekstu narracyjnego - może być jedynie cechą, przypadłością, kategorią bytu realnie przyporządkowaną formie substancjalnej, którą każdy człowiek realizuje, czyli ludzkiej naturze. Natura zaś ma być związana tylko z rozumem i jego unikatową zdolnością zjednoczenia się z absolutem - Bogiem - ten stan może osiągnąć nie kto inny, jak tylko owi dobrzy ludzie. Udaje się im to jedynie wtedy, gdy - jak naucza już starszy nieco do Boccaccia Mistrz Eckhart - skupią się na sobie, co im tym łatwiej przychodzi czynić, że są przecież s a molubni - do tego stopnia, iż zapomną o wszystkich poznanych rzeczach, a w końcu nawet i o sobie samych. Tylko ci, którzy „przyswoili sobie istotę wszystkich cnót [...], wiedzą, że najlepszą i najszlachetniejszą rzeczą, do której można dojść w tym życiu, jest milczeć i pozwolić działać i przemawiać Bogu"14. Dlatego też od takich podmiotów niewiele możemy się dowiedzieć o otaczającym je świecie czy jakiejś rzeczywistości ponadzmysłowej - świat jest przygodny i mylący (zagłusza chaosem informacyjnym), rzeczywistości ponadzmysłowej zaś nie daje się w ogóle opowiedzieć, skoro „[w] wieczności nie ma żadnego «przed» ani «po»"15. Nie daje się opowiedzieć zatem także przyjaźni etycznej, ponieważ rozgrywa się ona poza czasem i przygodnością. Nie dotyka jej zachłanność słowa, lecz tylko oko rozumu.

Opowiadanie przerywa milczenie i ciszę - zamiast pomagać duszy, dziś bardziej znanej jako umysł, w koncentrowaniu się na sobie, wprowadza do niej zgiełk zewnętrznych uczynków, rzeczy i zdarzeń. Reanimuje pamięć, rozgrywa się w czasie wypowiedzi (bądź lektury), jako takie należy więc do porządku przypadłościowego - akcydentalnego. Inaczej mówiąc, po prostu jest tylko ludzką cechą, jednym z wielu rodzajów naszej aktywności, takich, powiedzmy, jak śpiew czy taniec.

\section{Ontologia opowiadania - rzecz o kruchej wieczności}

Opowiadanie, które nie służy samodoskonaleniu się narratora, cechuje podmiot ontycznie słaby, uwikłany w to, co przygodne i efemeryczne. Dlatego Walter Benjamin i Paul Ricoeur ${ }^{16}$ sztukę opowiadania dostrzegli w wymianie

\footnotetext{
14 Mistrz Eckhart Kazania i traktaty, przeł. J. Prokopiuk, PAX, Warszawa 1988, s. 297-297.

15 Tamże, s. 203.

16 Zob. P. Ricoeur O sobie samym jako innym, przeł. B. Chełstowski, Wydawnictwo Naukowe PWN, Warszawa 2003, s. 271.
} 
doświadczeń z zakresu mądrości praktycznej.„Doświadczenie przechodzące z ust do ust - pisał Benjamin - jest źródłem, z którego czerpali wszyscy narratorzy. A między tymi, którzy spisali historie, są też ci wielcy, których zapis najsłabiej odróżnia się od mowy wielu bezimiennych narratorów"17. Wielkie historie zakorzenione są w małych opowieściach, które zwykle wyrażają afirmację życia, sprzyjają zawiązywaniu się wśród opowiadaczy przyjaźni, dostarczają zdroworozsądkowej wiedzy o tym, co komu przystoi, a co nie. Najbardziej dojrzałym produktem takiej mądrości jest kultura ludyczna, zasadniczo rozwijająca się w obrębie kultur oralnych, spontaniczna, wielogłosowa, ironiczna i prześmiewcza. Powieść stanie się jej najlepszym medium. Kultura ta nie stworzyła jeszcze hierarchii rodzajów i gatunków rzeczy - dominują w niej określenia rzeczy poprzez listy ich cech.

Ale to wszystko oznacza, że cała metafizyczna rama interpretacyjna zdaje się zupełnie chybiona wobec zdarzenia fabularnego opisanego przez Boccaccia. Nadal próbuję spojrzeć na nie z perspektywy jego osnowy medialnej - i przedstawić pewien zarys ontologii opowiadania. Częściowo tylko korzystam z narratologii, której pole badawcze daleko wykracza poza moje kompetencje i zainteresowania. Interesuje mnie nie temat, nie „co" przywołanych opowieści, lecz „jak”, forma ich przekazu, którą dziś nazwalibyśmy storytelling. „Teraz opowiem wam to, co sam usłyszałem od kogoś, komu opowiadano o zdarzeniu, «które raczej na kłamliwy wymysł niźli na prawdę wygląda»"18, ale - chciałoby się dodać - to przecież tylko jeszcze le piej dla nas. Na czym miałaby polegać atrakcyjność takiej zabawy, większa niż wszechogarniający strach przed bezlitosnym zabójcą?

Jeśli przy próbie odpowiedzi na to pytanie zrezygnujemy z taniego psychologizowania, przypisywania domniemanych znaczeń jedynie pewnym przeżyciom, wydarzeniom psychicznym, to pozostaje nam postępowanie strukturalistyczne, polegające na przyjęciu i postulowaniu pewnego kodu konwencji komunikacyjnej ${ }^{19}$. Otóż schemat narracyjny, o którym tu mowa, ma w sobie zakodowany niejako samonapęd, mechanizm samocelowej, bezinteresownej powtarzalności. Jeśli przyjmiemy, że opowiadanie polega - jak

17 W. Benjamin Der Erzähler. Betrachtungen zum Werk Nikolai Leskows, w: tegoż Illuminationen. Ausgewählte Schriften, Suhrkamp, Frankfurt am Main 1969, s. 410.

G. Boccaccio Dekameron (wybór), przeł. E. Boyé, CIL Polska-Kolekcje Sp. z o.o., Warszawa 2000, S. 115.

19 Zob. U. Eco Nieobecna struktura, przeł. A. Weinsberg i P. Bravo, Wydawnictwo KR, Warszawa 2003, s. 68. 
chcą narratolodzy - na relacjonowaniu, uobecnianiu wydarzeń realnych bądź wyimaginowanych, które nie są zmysłowo dane słuchaczowi ${ }^{20}$, to każde takie wydarzenie - przedmiot opowieści, historia opowiadana - nabiera znaczenia w samoodnoszącym się do siebie akcie wypowiedzi narracyjnej. W każdym kolejnym tym samym, ale nie takim samym. Opowiadanie domaga się zaistnienia, co jest możliwe tylko w czasie, który zapożycza ono ze swojej własnej wypowiedzi względnie (z czasu potrzebnego do) własnej lektury ${ }^{21}$. Można je z tego względu potraktować w kategoriach gry, której istotą jest autoprezentacja: istnienia opowiadania nie da się oddzielić od jego wykonania, wykonanie zaś ma charakter powtórzenia, a każde powtórzenie jest równie pierwotne ${ }^{22}$. Cóż to jednak znaczy dla czasu opowieści? To mianowicie, że nie jest on tożsamy z czasem aktu wypowiedzi, nie ogranicza się wyłącznie do czasu snucia opowieści bądź czytania lektury. Samocelowa powtarzalność niepowtarzalności tego samego-jakkolwiek paradoksalnie to brzmi - otwiera nas na transcendencję... w immanencji na wieczność. Nie jest to wszakże paraliż czasu, w którym uwięzione są byty idealne. Teraz opowiadają nie „ludzie wiedzy”, lecz osobnicy, którzy wyrwali się z obszaru mitu, wsłuchani w horyzontalną dal i snujący o niej niekończące się - można być dodać: już w kopernikańskim, horyzontalnym nieskończonym świecie - opowieści, i żadna z nich nie zawiera absolutnej prawdy, żadna nie jest o całości.

Przyziemni narracyjni osobnicy obcują z wiecznością, którą fenomenologicznie można by opisać jako kruchą nieśmiertelność stawania się - pojawiania się tego, co nowe, w odtwarzaniu starego. Im większy zostawiamy margines swobody na opowiadanie, tym bardziej ulegamy jego czarowi i złudzeniu, że nie zna ono granic, że istnieć to opowiadać - esse est narrare - lub inaczej: stawać się w opowiadaniu. W rekonstruowanej tu ontologii opowiadania zakłada się, że niewyczerpanej poznawczo naturze poszczególnych rzeczy i zdarzeń składających się na doświadczany przez nas świat odpowiada nasza potrzeba nieskończonego powtarzania ich narracyjnych przedstawień, w których nie sposób precyzyjnie oddzielić prawdy od fikcji, faktów od opowieści. Boccaccio zgodziłby się z Arystotelesem, że opowiadana historia tak samo jak poezja to naśladowcze przedstawienia zdarzeń,

20 Zob. P. Ricoeur Czas i opowieść, t. 2, s. 125-126, 132.

21 Zob. tamże, s. 134, 140.

22 Zob. H.-G. Gadamer Prawda i metoda. Zarys hermeneutyki filozoficznej, przeł. B. Baran, Inter Esse, Kraków 1993, s. 133-138. 
wniósłby jednak zastrzeżenie co do tego, że pierwsza (historia) musi dotyczyć wydarzeń rzeczywistych, a druga (poezja) prawdopodobnych ${ }^{23}$. Wiedział bowiem, że wejście w jednostkowe zdarzenia, uczucia i myśli bohaterów domaga się nie dramatu, lecz diegezy właśnie - naśladowania przez opowiadanie historii, polegające na osłanianiu prawdy "pięknym okryciem zmyśleń"24. Dla nas współczesnych brzmi to dość banalnie, ponieważ wiemy - to samo co Ricoeur - że najdalej w odzwierciedlaniu ludzkiej psyche zaszła powieśćc ${ }^{25}$.

Opowiadanie dzięki momentowi bezinteresownej powtarzalności n i e p o w t a r z l n e g o wykazuje pokrewieństwo z fenomenem enumeracji, wyliczeń i list w kulturze, który opiera się także na nieskończonym wymienianiu i wyliczaniu czegoś ostatecznie niepoliczalnego i niewymownego, co domaga się nieustannego wymyślania i mnożenia słów. Umberto Eco tak tłumaczy to zjawisko na przykładzie literatury:

Homer [...] uciekał się do list, ponieważ brak mu było słów, języka i ust, i w ten sposób topos niewymownego na wiele wieków zdominował poetykę listy. Jednak w stosunku do list Joyce'a czy Borgesa jest oczywiste, że autor wcale nie tworzy wykazów dlatego, że nie wie, jak mógłby się inaczej wyrazić, ale dla chęci mówienia par excellence, dla hybris i zachłanności słowa, dla radosnej (rzadziej obsesyjnej) wiedzy o wielości i nieograniczoności. ${ }^{26}$

Opowiadanie jest właśnie takim mówieniem par excellence - w nim słowo jest zachłanne, pragnie ogarnąć nieskończoność i nieograniczoność, zapełnić przestrzeń, jaka roztacza się między zakładaną pełnią istnienia a pustką. Zachłanność i pycha - gr. hybris - nie przynależą tu do podmiotu techniki, który dominuje nad światem i zamienia go w swój przedmiot do obróbli i eksploatacji. Tak jak zachłanność podmiotu techniki bierze się z chłodu i przemocy pojęć, tak zachłanność narratora - a to już przyjaciel Eco, Roland Barthes - z samej radości i rozkoszy mówienia: „j e s z c z e, je s z c z e,

23 Arystoteles Poetyka, przeł. H. Podbielski, Zakład Narodowy im. Ossolińskich, Wrocław 1983, s. 26. 
je s z c ze tr o c hę! Jeszcze jedno słowo, jeszcze jedno święto!"27. Tylko w raju mnożących się i spółkujących ze sobą słów może się pojawić nieskończoność i niewyrażalność świata jednostkowych rzeczy i zdarzeń. Podmiot techniki konstruuje i instrumentalizuje świat, a nie opowiada go. To zasadnicza różnica. Opowiadanie jest także z porządku „natury” - takiej wszelako, która naszą samolubność potrafi - paradoksalnie - łączyć z równie namiętnym i zachłannym pragnieniem bliźnich. Immanuel Kant upatrywałby jego źródeł w aspołecznej towarzyskości, w której nierozerwalnie ścierają się ze sobą skłonność do współżycia z bliźnimi ze skłonnością do izolowania się od nich.

Miotani sprzecznymi skłonnościami bycia razem i osobno, uciekamy się też do opowiadania. Snując opowieści, jednocześnie otwieramy i zamykamy się na innych. Dają one nam, narratorom, głos, otwierają przed nami perspektywę na nieskończone możliwości fikcyjnego modelowania siebie w sytuacji, gdy to, co opowiadamy, nigdy nie jest dane we własnej osobie - zawsze jest przecież tylko przywołane, przekazane, opowiedziane. Paradoksalność medium - łączy i dzieli zarazem - wyostrzy się nam jeszcze przy okazji telegrafu, ale o tym za chwilę. Jesteśmy przy opowiadaniu - jego paradoksalność przejawia się w tym, że każde odtworzenie opowieści jest sposobem jej istnienia, każde jest tak samo pierwotne. Każdy akt wypowiedzi - czas przeznaczony na nią (czas lektury lub opowieści ustnej) - bierze udział w trwaniu tego wiecznie pierwotnego, fikcyjnego czasu opowieści zawartego w pewnym quasi „wtedy" ${ }^{28}$.W nim opowieść nie ma więc ani początku, ani końca - zawsze taka sama w tym, co ją różni od każdego aktu jej snucia. I tak zapewne należałoby rozumieć Benjamina, gdy istotę opowiadania dostrzega on w tym, że „unika [ono] wszelkiej rozrzutności. Zachowuje siłę zgromadzoną w swym wnętrzu i dzięki temu może się rozwijać, nie zważając na upływ czasu"29.

Powtarzalność to uniwersalny pamięciowy mechanizm praktyk religijnych - mantry w buddyzmie i hinduizmie, kołowrotki modlitewne w klasztorach buddyjskich, różaniec w katolicyzmie itp. Tradycja filozoficzno-religijna tłumaczyła zwykle ten fenomen anamneza, wiarą w istnienie prawd wrodzonych, których poznanie polega na przypominaniu sobie tego, co wiemy już od zawsze.Wsamocelowej powtarzalności niepowtarzalnego

\footnotetext{
27 R. Barthes Przyjemność tekstu, przeł. A. Lewańska, Wydawnictwo KR, Warszawa 1997, s. 14.

28 Zob. P. Ricoeur Czas i opowieść, t. 2, s. 126, 134-135.

29 W. Benjamin [Trzy fragmenty o sztuce opowiadania], przeł. P. Bukowski, „Teksty Drugie” 2000 nr 3, s. 236.
} 
właściwej opowiadaniu ukryty jest ten sam mechanizm maszyny pamięciowej. Opowiadanie, skierowane na wieczność - na udział narratora w stawaniu się opowiadanych rzeczy, w ich kruchej nieśmiertelności, jako się rzekło - ociera się o rutynę i pospolitość. Historie biblijne, nawet te spośród nich zapisane językiem ubogim, czasem wręcz niedbałym ${ }^{30}$, mogą stanowić szlachetny wyjątek, usprawiedliwiony wszakże przez ich "prawdziwość". Opowieść literacka czerpie to, co pospolite, przez zakorzenienie w opowieści ustnej jako swej prefiguracji, w tym, co przypadkowe, w zdarzeniowym sposobie istnienia, którego nie zna ani idealny świat platoński, ani nowoczesny świat abstrakcyjnych praw naukowych. Opowiadane przygodne rzeczy i zdarzenia nie wykluczają fikcji, raczej ją zakładają, wzajemne się dopełniają: opowieść stanowi część życia, oderwana od życia dla literatury na rozmaite sposoby do niego powraca ${ }^{31}$. Oto wieczność krucha - jedyna nam dostępna. Tam, gdzie ktoś bezinteresownie dzieli się swoim czasem - który musi przeznaczyć na wypowiedź lub lekturę - z niezmiennym czasem opowieści, występującym zawsze w tym samym „wtedy”, rzeczywistym bądź wyimaginowanym.

\section{Monte Christo, telegraf i natura medium}

Pozostańmy jeszcze chwilę przy literackiej reprezentacji zarazy. Albert Camus pisze Dżumę w epoce mediów elektronicznych: radia, kina, telegrafu i telefonu. Tak jak obecnie, w czasie pandemii koronawirusa, mamy problemy z przeciążonymi serwerami z powodu dużej liczby wejść na pewne strony internetowe, tak wówczas - w relacji Camusa:

Telegramy stały się wtedy naszym jedynym ratunkiem. Istoty złączone zrozumieniem, sercem i ciałem musiały ograniczyć się do szukania znaków tej dawnej wspólnoty w drukowanych literach depeszy złożonej z dziesięciu słów. A ponieważ sformułowania, których można użyć w depeszy, wyczerpują się szybko, długie wspólne życie czy bolesne namiętności streściły się rychło w wymianie gotowych formuł jak: „Mam się dobrze. Myślę o tobie. Serdeczności".32

Tak charakteryzują tłumacze np. Ewangelię według świętego Jana, zob. Biblia Tysiąclecia. Pismo Święte Starego i Nowego Testamentu, Pallottinum, Poznań 1980, S. 1214. 
Telegraf - pierwsze medium elektryczne - jak widać, redukuje opowiadanie, mówienie par excellence, do prostego komunikatu, w którym nie ma miejsca na zmyślenia ani fikcje. Idzie o problem medium. Telegram nie czerpie już niczego z pospolitości - z wypraw w codzienność, potoczny język itd. Jego adresaci najczęściej przyjmowali go od listonosza drżącymi rękoma z myślą o śmierci. Wygląda na to, że on też, podobnie jak opowiadanie, jest ekspresją naszej a s połecznej towarzyskości, że łącząc ludzi ze sobą, jednocześnie ich od siebie izoluje - wzbudza sieć niedomówień i podejrzeń. I taka zdaje się natura medium w ogóle - paradoksalna, farmakoniczna, diaboliczno-symboliczna, zgodnie z etymologią obydwu tych greckich słów: diaballein - przerzucać, oczerniać, atakować, oddzielać; symbállein - łączyć, przypasować do siebie ${ }^{33}$. Telegram zacytowany przez Camusa to zwykła formuła grzecznościowa, obciążona podejrzeniem co do swej wiarygodności: a może nadawca chce mnie tylko uspokoić - „mam się dobrze” - i dlatego okłamuje mnie? To wielce pouczające w sprawie natury medium w ogóle, którą dotychczas rozważałem tylko na przykładzie opowiadania. Okazuje się, że telegram tak samo jak opowiadanie to nie zwykłe narzędzie, służące nam jedynie do przekazania pewnej wiadomości, po czym możemy je spokojnie odłożyć na bok, zakładając, że wiadomość ta może istnieć niezależnie od niego. Otóż nie, rzecz ma się tak, że wiadomość jest niejako zanurzona w medium - i nie istnieje poza nim. Wygląda więc na to, że to nie medium jest przekazem, lecz ślad medium przechowuje się w przekazie ${ }^{34}$. Ślad w postaci konwencji komunikacyjnych, które ustalają reguły tworzenia medialnych znaczeń w opowiadaniu tym kodem był mechanizm bezinteresownej powtarzalności.

Co z telegrafem? Jego literackim reprezentacjom udało się ukazać coś więcej niż tylko diaboliczno-symboliczną naturę medium. Przyczynił się do tego Aleksander Dumas - tym razem jednak bez udziału zarazy. Tytułowy bohater jego powieści z 1844 roku, hrabia Monte Christo, powodowany zaiste diaboliczną żądzą zemsty na swoich dawnych oprawcach, wykorzystuje telegraf do dezinformacji - sprawia, że do ministerstwa w Paryżu dociera wiadomość o powstaniu w Barcelonie, czego efektem jest gwałtowny spadek wartości obligacji hiszpańskich. Wrogowie hrabiego masowo zaczynają je wyprzedawać, podczas gdy on nabywa je przez pośredników. Całe

33 Zob. Online Etymology Dictionary, https://www.etymonline.com/word/devil, https://www. etymonline.com/search?q=symbol (13.04.2020).

34 Zob. S. Krämer Medium, Bote, Übertragung. Kleine Metaphysik der Medialität, Suhrkamp, Frankfurt am Main 2008. 
zamieszanie zostaje wyjaśnione następnego dnia, kiedy w prasie ukazuje się informacja, że na Półwyspie Iberyjskim panuje spokój, a docierające stamtąd sygnały telegraficzne musiały zostać „odczytane źle z powodu mgły" ${ }^{\prime 35}$. Na tym polegała intryga. Ale nie o nią tu chodzi. Ważniejszy dla mnie jest stosunek głównego bohatera do telegrafu. Mówi wprost, że nie chce zrozumieć zasad działania tego urządzenia. Świadomie unika spotkania z ludźmi, gdyż - jak twierdzi - „zmusiliby mnie, abym zrozumiał rzeczy, o których nic nie chcę wiedzieć, i którzy wytłumaczyliby mi tajemnice, na których sami się nie znają"36. Ten zabawny, jakby się nam dziś zdawało, wątek mgły zakłócającej odbiór sygnałów staje się zrozumiały, jeśli zważyć, że Francuzi w połowie XIX wieku korzystali z telegrafu optycznego, sto lat później - w relacji Camusa - oczywiście z elektrycznego. Zaprezentowane po raz pierwszy w 1792 roku urządzenie francuskiego wynalazcy Claude'a Chappe’a było zbudowane z umieszczonego na wieży wysięgnika z obrotowymi belkami podobnymi do podwójnego semafora. W pierwszej połowie XIX wieku cała sieć tych urządzeń pokryła Francję. Między stacjami przekaźnikowymi przekazywały one dwa słowa na minutę.

Nie chodzi tu tylko o kwestie inżynieryjne, lecz raczej o coś znacznie bardziej uniwersalnego, co dotyczy w ogóle fenomenu medium komunikacyjnego. $\mathrm{O}$ to, że technika jest równie nieprzejrzysta i niewiarygodna w komunikowaniu, jak i sami ludzie - zawsze podejrzana, przyjazna i wroga zarazem: „Wystarczy, że straciłem już wszelkie złudzenia co do ludzi”37 - powiada hrabia. Razi go ich fikcyjność, zamiast żyć - grają, występują na scenie, nie liczy się już to, kim są, lecz to, za kogo chcieliby uchodzić. Wraz z nimi zaczyna się historia nowoczesnego społeczeństwa intymnego. Pod trupią maską tajemniczej postaci z opowiadania Poego inni zamaskowani uczestnicy balu karnawałowego w zamku księcia Prospera nie odkrywają niczego namacalnego. W tym samym czasie Dumas tak opisuje historię jednej ze swoich postaci literackich: „Zadomowił się mniej więcej w tym paryskim towarzystwie, które tak łatwo przyjmuje cudzoziemców i obchodzi się z nimi, ceniąc każdego nie wedle tego, kim jest, ale wedle tego, za kogo chce uchodzić"38. To skądinąd znany

A. Dumas Hrabia Monte Christo, t. 2, przeł. K. Łukaszewicz, Hachette Polska, Warszawa 2013, S. 41.

36 Tamże, s. 31.

37 A. Dumas Hrabia Monte Christo, t. 2, s. 31.

38 Tamże, s. 184. 
socjologom i historykom fenomen kultury nowoczesnej, z powstającą w niej sferą publiczną, w której ludzie pojawiają się w określonych rolach. Sam zresztą Monte Christo wybiera dla siebie rolę (tytul) hrabiego, którym w rzeczywistości nie był. Żyje w świecie, gdzie liczy się tylko to, co dane jest zmysłom - esse est percipi - istnieć to tyle, co być postrzeganym, i tak długo to przekonanie jest trafne, jak długo nie uświadomi sobie, że między postrzegającym a rzeczą postrzeganą istnieje jeszcze coś trzeciego, medium jako „idea” przedmiotu jego znak, przedstawienie. $Z$ chwilą gdy sobie uświadomi istnienie medium, przestaje już istnieć dla niego cokolwiek poza nim (medium) samym. Ale odtąd jest to już tylko medium pozbawione zdolności łączenia ze sobą ludzi, zapełniania ich wspólnego świata sensem. Wszystko wokół nich pokrywa się niejako z nimi samymi - z wytworami ich własnych projektów.

Odtworzona tu argumentacja na rzecz tzw. idealizmu epistemologicznego, zwanego też subiektywnym, autorstwa irlandzkiego filozofa George'a Berkeleya, musiała być znana także Dumasowi. Niekoniecznie w rezultacie specjalistycznych studiów. Intelektualne środowisko ówczesnego Paryża żyje ideami pozytywistycznymi - doktryny minimalistycznej, w której formowaniu miał udział Berkeley przez swój empiryzm i związane z nim odrzucenie istnienia ogólnych idei, co przekładało się na fenomenalizm, czyli przekonanie, że nie ma różnicy między „istotą” a „zjawiskiem”. W maksymalistycznych, metafizycznych doktrynach zakłada się, że zjawiska - to, co zmysłowo postrzegalne - są tylko różnymi przejawami jakiejś rzeczywistości ponadzmysłowej, transcendentnej. Stanowisko pozytywistyczne podważa tłumaczenie zjawisk obecnością czegoś pozazjawiskowego, jakichś utajonych przed ludzkimi zmysłami istnień. Postrzegamy tylko zewnętrzne kształty rzeczy - nie ma żadnej głębi pod ich powierzchnią. Cały ten znany nam metafizyczny podział właściwości rzeczy - ludzi, przedmiotów, artefaktów - na istotne i akcydentalne jest wobec tego fałszywy i zbyteczny. Ciekawość hrabiego Monte Christo budzi więc tylko sam wygląd urządzenia. Jest on dla niego nośnikiem znaczeń, które nasuwają mu skojarzenia z imaginacyjnym bestiarium: „zapragnąłem przyjrzeć się z bliska tej poczwarce, która pociągając za sznurki, daje ze swej skorupy znaki innej takiej poczwarce”, to takie "ogromne białobrzuche owady z czarnymi, cienkimi łapami”, , przychodziły mi wtedy do głowy dżiny, sylfy, gnomy, słowem - jakieś tajemne moce" ${ }^{\prime 39}$. Tak musiały mu się przedstawiać owe wysięgniki - wielkie łapy falujące na wieży. Przy tych swojskich i demonicznych zarazem znaczeniach chciałby pozostać - wystarczą mu one do 
zrozumienia narzędzia, za pomocą którego pokona swoich wrogów: „A ja, do licha, chcę zachować złudzenie, że to wielkie owady" ${ }^{\prime 40}$.

To chyba modelowy opis mechanizmu czarnej skrzynki: „nie chcę nic rozumieć" z jej działania, ponieważ jeśli je poznam, to przestanie być ona dla mnie niewiadomą - medium jako środek utraci wtedy swoje właściwości, przede wszystkim tę najbardziej pożądaną, czyli niewidzialność. Ostateczny argument, który ma uzasadnić niechęć Dumasowskiego bohatera do zrozumienia nowej technologii komunikacyjnej, brzmi więc następująco: „W chwili, gdy coś zrozumiem, nie będzie już telegrafu - będzie tylko znak, który jakiś pan Duchtel przesyła prefektowi Bajonny, przebrany w te dwa greckie słowa - tele graphein"41.

W opowieści literackiej telegraf występuje w znanej nam roli demona - okrutnego (metaforyka owadów, poczwarek) pośrednika z „czarną łapą” zemsty. Słyszy się tu frazę z Księgi Samuela - „kiedy anioł wyciągnął rękę nad Jerozolimą, by w niej dokonać spustoszenia" (2 Sm 24, 16). Dumas w swoim fenomenologicznym opisie telegrafu odsłania medium jako pośrednika, który nie jest jedynie neutralnym nośnikiem sensu, ponieważ sam uczestniczy w jego generowaniu. Gdy ogromne białobrzuche owady żłobią swymi czarnymi łapami w powietrzu pismo - tu znów trzeba by się powołać na etymologiczne znaczenie greckiego słowa graphein: pisać, a w bardziej źródłowym znaczeniu: wydrapać, wyryć, wycią ć $^{42}$ - to nie sposób oczekiwać, żeby wytłaczany przez nie sens pokrywał się z tym tylko, co przekazują same znaki. Nie da się więc traktować medium tylko hermeneutycznie, ograniczając się do interpretacji przekazywanych przez niego komunikatów. Złowieszcza materialność i nieprzejrzystość telegrafu - „jakieś tajemne moce” - ukazują go jako demona, ogniwo wiążące między pełnią sensu a pustką nagiego istnienia. Medium, pozwalając na interakcję między tymi dwiema stronami bytu, umożliwia sens i zarazem weń ingeruje.

\section{***}

Proponowana tu refleksja nad mediami jest pewną krytyką metafizyki. Sens nigdy nie jest gotowy, nie istnieje przed medium, które jest niczym innym

\footnotetext{
40 Tamże.

41 Tamże.

42 Zob. Online Etymology Dictionary, https://www.etymonline.com/word/write (13.04.2020).
} 
jak tylko konstruktem społecznym - uwikłane w różne praktyki społeczne, nie rządzi się odrębną racjonalnością. Oto dlaczego snucie opowieści zakorzenione jest w codzienności, a telegraf - w świecie mitów i legend (stąd owe dżiny, sylfy i gnomy). Pośrednik nigdy nie może być (absolutnie) przezroczysty - bezbarwny, niezatrzymujący na sobie uwagi, niemający nic do powiedzenia od siebie posłaniec. Problem polega jednak na tym, że komunikacja ma niejako naturalną skłonność do obiecywania takiej przezroczystości, utopijnej, pierwotnej jedności presemiotyki, jak nazwał ją kiedyś Władysław Panas. Inaczej mówiąc, do zawiązywania komunii osób, wspólnoty, polegającej na ich wzajemnym obdarowywaniu siebie sobą, zawieszeniu wszelkiej pośredniości, na stopieniu się w jedno. A to by znaczyło, że w samych mediach, środkach służących porozumieniu i zbliżeniu się ludzi, ukryte jest jakieś - chciałoby się powiedzieć - ontologiczne kłamstwo. Dlatego działają farmakonicznie: służą zbliżeniu, zachowują różnice obu stron i jednocześnie mają tendencję do maskowania tych różnic, oszukiwania, tworzenia fałszywej jedności. Obiecywana przez nich jedność ukrywa dualizm nadawcy i odbiorcy, ich odmienność i odrębność ontologiczną; zafałszowuje podstawowe doświadczenie naszej niepowtarzalności - samotności i niewymowności.

Zdaje się, że to, co zwie się mądrością praktyczną, nie tyle reflektuje, ile respektuje takie właśnie działanie mediów. Tłumaczyłoby to chociażby intrygujące mnie na początku zachowanie florenckiej młodzieży w czasie zarazy - oddać się erotycznej rozkoszy snucia opowieści, przez którą niczyja godność, ani narratora, ani słuchacza, nie zostanie naruszona, każdy zachowa tożsamość, a jednocześnie nikt nie będzie liczył czasu spędzonego razem. Cóż jednak z tego rodzaju trywialnej obserwacji miałoby wynikać dla teorii mediów? To mianowicie, że teoria ta tłumaczyłaby świadomość paradoksalnego działania mediów tym, iż zmuszają one swych użytkowników, czyli nas, do interpretacji przekazów i jednocześnie pozostawiają nas w przekonaniu, że żadne przekazy nie wyczerpują treści odnośnych rzeczy i zdarzeń, niezależnie od tego, czy są one fikcyjne, czy rzeczywiste. W rezultacie przekazy te nie są też fundamentalistyczne i nie usprawiedliwiają w relacjach międzyludzkich ani przemocy, ani hegemonii. Nie wyczerpują treści rzeczy, ponieważ same media uczestniczą w tworzeniu tego, co przekazują, w rezultacie czego rzeczy i zdarzenia w każdym przypadku zawsze są czymś więcej i czymś innym niż to, co o nich - z mediów - wiemy. Otóż - i to chyba clou moich rozważań - takie rozumienie medium może nas uchronić przed samotnością i pustką - horror vacui - dramatem nowoczesnej egzystencji w świecie, w którym odnajdujemy tylko siebie. Czas zarazy okazał się laboratorium takich dramatycznych 
doświadczeń, a historia pokazuje, że literatura potrafiła go lepiej wykorzystać dla swoich celów niż filozofia.

\section{Abstract}

\section{Jan Hudzik}

MARIA CURIE-SKŁODOWSKA UNIVERSITY (LUBLIN)

From Narrative to Telegraph: (Not/ust) Plague Literature and the Problem of the Media

Hudzik proposes a philosophical theory of the media through a discussion of global plague literature. He begins by asking why the characters of The Decameron tell each other banal stories, then he treats narrative as a medium and distinguishes metaphysics from ontology of narrative, based on (modern) subjects using practical wisdom. Finally, he analyses the literary representations of the telegraph (Camus, Dumas). What do they contribute to our understanding of the media?

\section{Keywords}

plague literature, medium, narrative, telegraph, metaphysics of narrative, ontology of narrative, media philosophy 